\title{
Biochemistry and Renal Function: Use of Inquiry-Based Teaching Sequences for Retrieval of Specific Concepts
}

\author{
Bioquímica e Função Renal: Utilizações \\ de Sequências Didáticas com Enfoque \\ Investigativo para Reaproximação de \\ Conceitos Específicos
}

\author{
Prislaine Pupolin Magalhães ${ }^{I \oplus}$ \\ Rodrigo Cardoso Oliveira ${ }^{I \odot}$ \\ Daniela Ponce ${ }^{I I I}$ \\ Silvia Regina Quijadas Aro Zuliani ${ }^{1 \odot}$
}

\section{PALAVRAS-CHAVE}

- Sequências Didáticas.

- Atividades Investigativas.

- PBL.

- Proteinúria.
I Universidade Estadual Paulista, Bauru, São Paulo, Brasil.

"Iniversidade de São Paulo, Bauru, São Paulo, Brasil.

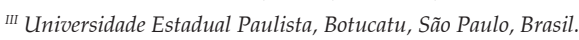




\section{KEY-WORDS}

- Didactic Sequences

- Inquiry-Based Teaching.

- PBL.

- Proteinuria.

\begin{abstract}
Current teaching proposals involve teaching strategies that seek to assist and encourage the construction of knowledge by the students, turning them into active participants during the learning process and these have been the subject of several researches. This article reports a didactic sequence carried out with students of applied training for the first year Medical Sciences USP - Bauru, and proposes, as part of its pedagogical design, Problem Based Learning (PBL) as the main teaching strategy. In this didactic sequence we used experimental investigative activities. A didactic sequence that includes investigative activities can be characterized as a gradual evolutionary process, with the objective of intertwining the scientific perspective and the students' conceptions, through wellplanned teaching and learning activities contextualized and empirically adapted to the student's reasoning. The objective of this work is to share an assertive experience of the application of a contextualized research didactic sequence that involved concepts ranging from the simplest chemical properties of biomolecules and ions to the association and discussion of a hypothetical clinical case involving proteinuria. Its pathophysiology consists of the excretion of protein in the urine, mainly albumin, and occurs when there is some damage to the kidneys. Therefore, the dosage of the protein fraction in urine (albuminuria) is mainly used for the early detection of chronic or acute kidney disease and can also be an instrument for the diagnosis of cardiovascular diseases. Therefore, one should be aware of the possible interferences and the various causes of errors inherent to this examination. In this way, through a didactic resource involving contextualized research experimental activities, having proteinuria as the key problem, we were able to re-approximate specific concepts and to value procedural and attitudinal knowledge, which is important for students in this training phase. In this proposal, the students were protagonists of the learning process, where they were able to raise and test their hypotheses, interconnecting knowledge, acquiring specific skills and competences, allowing reflection on the importance of fundamentals and applications of the basic sciences. The purpose of the investigative and contextualized didactic sequences is to form autonomous subjects, who know how to make decisions and work in teams and have a sound and critical understanding of how scientific knowledge evolves and is related.
\end{abstract}

Recebido em: 9/5/19

Aceito em: 30/5/19

\section{INTRODUCTION}

The curriculum of higher education courses in the area of health, such as Medicine, for example, has been relinquishing its traditional characteristics and undergoing major reforms directed at the acquisition of competencies that are required in the contemporary world. Among the strategies used for the curricular reforms, we can highlight the flexible curricular structure, which can create possibilities (time) for other activities that favour the student's humanistic development; and the use of these new teaching strategies that prioritise active participation in student-centred approach to their learning. For this kind of approach we can cite, for example, Problem-Based Learning (PBL)1.According to Conceição and Moraes², PBL is currently the most commonly used methodology in Brazilian medical courses, as it promotes cooperative learning focused on the active construction of knowledge, giving the learners greater rapport between them and optimizing interaction between teaching, care and research.

Following this trend, changes were made to the Ribeirão Preto Medical School of the University of São Paulo (USP), which in 1993 restructured and implemented a new curriculum, whereby the course, now entitled Medical Sciences Course, was split into three phases (basic, clinical and internship), each lasting two years. In this proposal, the traditional subjects were condensed, and optional subjects were included in the first three years of the course, with mention of so-called self-learning resources. This restructuring also afforded free time for students to have earlier contact with the health care network, in order to streamline their ethical and humanistic development, as well as offer them the opportunity to de- 
vote time to research in the institution's scientific initiation programs ${ }^{3}$.

The pedagogical project of the Medicine course at USP Bauru, which is still under development, is built on the understanding that the student should be prepared to become a professional and citizen who will participate in knowledge development processes ${ }^{4}$. The pedagogical activities developed are centred around the student and his learning process, with the teacher playing the role of facilitator in the process, focusing on Problem-Based Learning (PBL) strategies and student involvement in the community since the start of the training process. The Medicine course in Bauru, started in 2018, upon opting to use these ideas in its pedagogical project, thus aligned itself to the National Curriculum Guidelines for Medicine Courses, approved in 2014. The expectation, therefore, is to train a more complete and secure professional, fit to meet the needs of the population and the labour market ${ }^{4}$.

In view of the foregoing, it is implied that traditional teaching will have been surpassed. Based on this premise, we detail in this work a didactic sequence (SD) with an investigative emphasis on the methodological proposal for the teaching of Biochemistry to students in the initial years of the Medical Sciences, Pharmaceutical and Biomedical undergraduate courses, among others. We can define a DS as a set of ordered, structured and coordinated activities for the fulfilment of certain educational goals, with a principle and an end result known both by the teachers and the students ${ }^{5}$. Thus we can understand DS as a set of planned activities to teach one or more concepts and/or contents, step by step, organized in accordance with the learning objectives that the teacher wants to achieve at any level of education. To achieve the learning objectives in a DS, planning plays a key role and should involve enough flexibility to meet student needs, engaging them, whetting their curiosity and relating various activities to the content, which in this case range from basic to clinical concepts.

The DS should, therefore, be composed of clear instructions and resources, taking one of several possible structures, fulfilled in various areas of knowledge. According to Zabala ${ }^{5}$, the students' learning process for a given content should underlie the structure of the DS, based on their alternative conceptions and learning difficulties. It should have learning objectives that emphasise the central role played by the student, addressing conceptual, procedural and attitudinal contents, as well as using diverse and multivariate didactic resources and strategies; expositive classes should not be the main focus (it is recommended that they correspond to $20 \%$ of the content at the most), and when they are used they should involve dialogue. Finally, procedural and formative assessment is recom- mended over the course of the DS. Investigative experimental activities are a good strategy, since active methodologies prioritise hands-on type learning practices.

There are two main types of experimental activity. Traditional experimental activities can largely be divided into demonstrative experiments, conducted only by the teacher for the students' appreciation, or situations in which the student conducts experiments, usually, however, by means of closed experimental scripts ${ }^{6}$, inserted into pre-printed handouts. The main aim is generally to demonstrate or prove theories, where the student usually has prior knowledge of the expected results, often told by the teacher himself. Investigative experimental activities, meanwhile, do not have a teacher as the single knowledge holder and do not follow recipe-like scripts; it is a contextualized active methodology, in which the student should engage in order to resolve a problem with the available apparatus. It involves stages of research, planning, formulation of hypotheses, work and discussions with peers, encouraging scientific thought, teamwork and the development of the students' own conclusions. Furthermore, in this proposal, the teacher acts like a mediator in the learning process, learning with the discussions brought by the students during the activity and reflecting, which makes the learning mutual and constructive, far from their so-called "comfort zone". In traditional experimental activity the teacher is considered the holder of the knowledge, providing explanations and strategies of how to arrive at the expected results, avoiding complications.

On the other hand, investigative experimental activities go beyond the recognition of phenomena, as they are planned to provide for the development of concepts and mental abilities related the processes of the science, making the laboratory experiences minds on and not only hands on. As previously mentioned, a constant error made by teachers during experimental classes would be proving theories. The fact that the experiment does not work or "goes wrong" does not change the theory, or annul it ${ }^{7}$. The philosophy and history of science show us the importance of reflecting on the phenomena for the construction of scientific knowledge, since science is constructed through a non-linear process of reflections, debates and clashes between researchers and research groups, some renowned and other almost anonymous, based on theoretical and phenomenological aspects, whose members have different beliefs, values, interests, knowledge and intentions. Moreover, we can consider the traditional experimental teaching methodology as outdated for contemporary students, who have easy and practical access to information.

Problematizing situations are crucial in investigative activities, in which the teacher sparks interest and instigates 
the students on the basis of a problem which, through its attempted resolution, leads to the development of explanatory hypotheses. Therefore, questioning, creating hypotheses and participating in the discussion are skills that afford better assimilation of the studied content. Stuart and Marcondes ${ }^{8}$ argue that:

If the student has the opportunity to follow and interpret the stages of the investigation, he will be capable of developing hypotheses, testing them and discussing them, learning about the chemical phenomena studied and the concepts that explain them, and achieving the goals of an experimental class that prioritises the development of cognitive skills and logical reasoning. (p.11)

The DSs that involve investigative activities may encompass basic concepts, as in this example, beginning with the Biochemistry and reaching the discussion of a pathophysiology related to a hypothetical case study. Biochemistry, in turn, is a fundamental discipline for health care courses. It comprises the study of life at a molecular level, being a multidisciplinary science that employs methods and strategies from different areas, which together can resolve problems. Therefore, as well as it being important for the student to have contact with a simple test tube and observe some simple organic reactions, it is indispensable to connect different concepts to understand the health-disease dialect. The contents of Biochemistry, largely experimental, may have qualitative and quantitative approaches and are still developed in an individualized manner in many courses, that is, one class about protein, another about lipids, etc. Generally in the first years, or the "basic cycle", the classes do not involve adequate critical analysis, probably due to the complexity of the specific concepts/contents, which set apart basic knowledge from clinical/pathological knowledge.

In the Health Sciences course, as well as didactic laboratories and their practices, the students' experience and understanding of the importance of Clinical Analysis Laboratories (CAL) in diagnosis, prognosis, treatments, evolution and prevention of illnesses ${ }^{9}$ is essential, with a permanent tie between clinical practice and clinical biochemistry. Studies conducted with more than 4,000 patients have shown that many consultations culminate in the request for complementary exams. According to Capilheira and Santos ${ }^{10}$, a laboratorial exam was requested for $67.6 \%$ of the patients. Among them, the urine examination is one of the most requested tests, as a simple exam that provides important information in metabolic triage, as well as presenting data to aid in the diagnosis and prevention of renal diseases ${ }^{11}$.
There is a technological mentality regarding laboratorial exams, as the practicality of kits or strips has meant that users have ceased to reflect on basic reactions or on how a given technique has improved, such as, for example, how reference values are determined. It is also necessary to consider which experimental cares to take, why and how to interpret those exams and how to choose the most appropriate method. Equally, understanding what "blank" or "samples" or "reference values" mean in a biochemical analysis. Consequently, with the didactic sequence proposed in this work, the student experiences all the stages of scientific knowledge, from the simplest chemical properties of the biomolecules to their practical application, such as in the case of the nephrology reported here.

Proteins in small quantity and of low molecular weight can be filtered by the glomerulus and reabsorbed in the proximal tubule, considering physiological proteinuria and albuminuria of less than $300 \mathrm{mg} / \mathrm{d}$ and $30 \mathrm{mg} / \mathrm{d}$, respectively ${ }^{12}$. Albuminuria levels between $30 \mathrm{mg} /$ day and $33 \mathrm{mg} /$ day are defined as second degree albuminuria, and its presence is a marker for incipient nephrology $y^{13}$. Third degree albuminuria, meanwhile, is characterised by an albumin level in the urine greater than $300 \mathrm{mg} /$ day, which level is already detected in the strip test, that is, qualitatively ${ }^{14}$. Nephrotic syndrome is defined as the presence of albuminuria at a greater quantity than $3 \mathrm{~g}$ in 24 hours and is generally found in glomerulopathies.

The pathophysiology of albuminuria remains a cause for studies and controversy. The most well-known theories are the overflow theory, which says that the cause is elevated hydrostatic pressure inside the glomerular capillary tufts, and the underfilling theory, which attributes the cause of the albuminuria to reduced oncotic pressure ${ }^{15}$. Abnormalities in the glomerular endothelium can also explain the loss of albumin by the glomerular barrier ${ }^{16}$. Therefore, for patients at risk of developing chronic kidney disease, that is, those with arterial hypertension, diabetes, autoimmune diseases, with a family history of kidney disease and the elderly, urine sediment analysis is recommended for qualitative protein testing.

If proteinuria is identified in the qualitative test, it is recommended that it be quantified in an isolated urine sample (Figure 1) through the protein (mg) to creatine (g) ratio, which presents an excellent correlation to proteinuria determined in urine sample in 24 hours ${ }^{17}$.

The presence of proteinuria implies a worse renal and cardiac prognosis, while its remission results in greater preservation of the kidney function and reduced cardiovascular events ${ }^{18}$. Pressure control is beneficial in the reduction of proteinuria and for the speed of CKD progression both in diabetic and non-diabetic patients ${ }^{18,19}$. Angiotensin-converting enzyme 


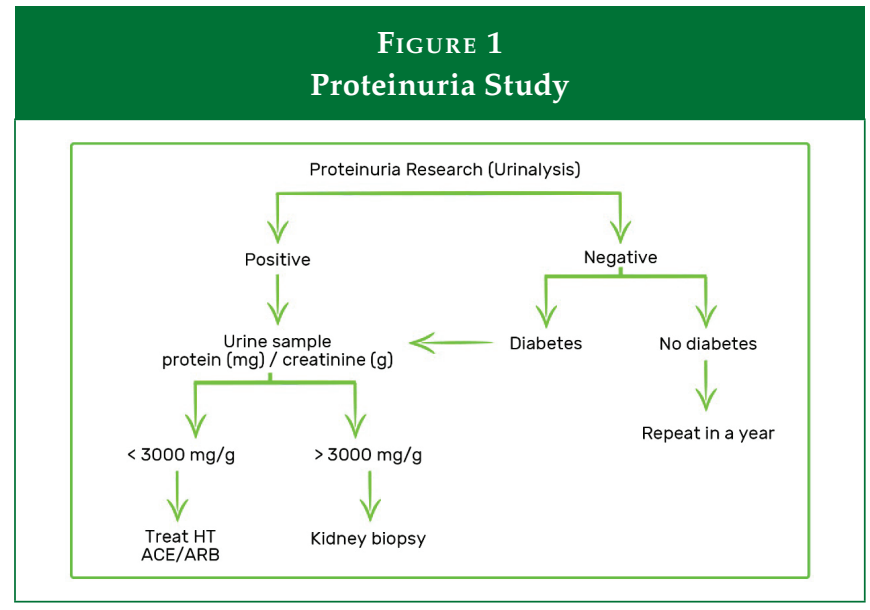

Source: Authors.

(ACE) inhibitors and angiotensin receptor blockers (ARBs) are the drugs of choice for treatment. Renal biopsy is recommended in the presence of nephrotic syndrome for the diagnosis and specific treatment of glomerulopathies, which includes immunosuppression. Drawing on these premises, this DS had the purpose of integrating the concepts discussed above.

\section{METHODOLOGY}

This DS was developed with 30 first-year students from the USP - Bauru Medicine course. The didactic sequence was proposed during module 4 (Homeostasis 1) and was conducted by the teachers of Biochemistry and Nephrology. The main objective of the module was to characterise the concept of homeostasis and the evolution of the different systems in the hydro electrolytic balance (absorption and excretion) and the acid-base generated by the renal system and its influence on the regulation of the systemic arterial pressure and on homeostasis. Based on the teachers' instructions and mediation, the students used their knowledge of renal physiology and biochemistry to plan and execute experiments in a sequence of lessons. The activities were executed in six groups of five students, and the experimental lessons occurred in the microbiology laboratory of the Bauru Dental School (FOB-USP). The students participated voluntarily in the sequence, and all the lessons were administered out of normal school hours.

The DS was developed in six 50-minute lessons. As mentioned, the majority of the classes were experimental, and the expository dialogue classes were dedicated to the stages of planning, systemization and discussion of the knowledge developed by the groups. The proposed DS had the prerequisite of basic biochemistry and can be reproduced by other higher education health science courses, such as Medicine, Biomedicine and Nursing, when discussing concepts of physiology involving homeostasis and the characterization of the hydro electrolytic balance (absorption and excretion) and renal acid-base. Therefore, based on the teachers' instructions and mediation, the students used their knowledge of renal physiology and biochemistry to plan and execute the experiments. Table 1 presents a summary of the six lessons proposed in the DS and their main objectives, the details of which shall be discussed in the description of each lesson.

\begin{tabular}{|c|c|}
\hline & $\begin{array}{c}\text { TABLE } 1 \\
\text { Summary table of the lessons and their main objectives }\end{array}$ \\
\hline Lesson & Objective \\
\hline 1 - Problematization & $\begin{array}{l}\text { Present the clinical case and the importance of discovering and quantifying the content present in unknown } \\
\text { sample " } \mathrm{X}^{\prime *} \text {. Discuss simple analytic methods and how they might help in the identification and quantifi- } \\
\text { cation of compounds. }\end{array}$ \\
\hline $\begin{array}{l}2 \text { - Understanding some Chemistry } \\
\text { and its analyses }\end{array}$ & $\begin{array}{l}\text { Familiarizing oneself with the concepts of analyte, standard solution and reagents and their meanings. } \\
\text { Choose the analyses that could help elucidate the clinical case, propose hypotheses and plan the experimen- } \\
\text { tal tests within the reasonable possibilities of the proposal. }\end{array}$ \\
\hline $\begin{array}{l}3 \text { - Activity in the Biochemistry } \\
\text { Laboratory: weighing a sample }\end{array}$ & $\begin{array}{l}\text { Learn about the functioning and care when using an analytical scale. Experience indirect weighing methods } \\
\text { for solutions, retrieving concepts of solution dilution. }\end{array}$ \\
\hline $\begin{array}{l}4 \text { - Activity in the Biochemistry } \\
\text { Laboratory - Part A }\end{array}$ & $\begin{array}{l}\text { Experience experimental investigative activities. Perform analysis test with the standard solutions chosen } \\
\text { in the plan. }\end{array}$ \\
\hline $\begin{array}{l}5 \text { - Activity in the Biochemistry } \\
\text { Laboratory - Part B }\end{array}$ & Perform biochemical qualitative analysis on unknown sample, "sample X". \\
\hline $\begin{array}{l}6 \text { - Activity in the Clinical Analysis } \\
\text { Laboratory (CAL) }\end{array}$ & $\begin{array}{l}\text { Visit a CAL. Familiarize oneself with the routine of the clinical analysis laboratory; immersion in this space, } \\
\text { learning about the routine of biomedics and clarifying doubts. Perform routine quick tests in the biomed- } \\
\text { icine laboratories and reflect on the importance and functionality of the kits used, reviewing the testing of } \\
\text { substance " } \mathrm{X} \text { " in this setting. }\end{array}$ \\
\hline Siummary & f the activities performed and formulation of the concepts involved in the process. \\
\hline
\end{tabular}

Source: Authors.

* Sample " $\mathrm{X}$ " is the unknown sample, consisting of a $0.05 \mathrm{~g} / \mathrm{mL}$ albumin solution. 
The groups were provided with test tubes and racks, plastic Pasteur pipettes, wash bottle with distilled water, Bunsen burner, platinum inoculation loops, digital thermometer, universal $\mathrm{pH}$ strip, double boiler at $100{ }^{\circ} \mathrm{C}$ and analytical scale. As well as these materials and equipment, the students could request other reagents, simple materials and equipment that they deemed necessary within the proposal. They were also informed that the presence of iron ions, creatinine and uric acid was discarded in the unknown sample " $X$ ". During the activities involving experimental biochemistry, if necessary, and from a practical perspective, the quantitative and/or qualitative chemical analysis concepts could be reviewed on an analytical semi-micro scale. For example, there are organoleptic properties, complexation and precipitation reactions, solubility and heat transfer, flame tests and $\mathrm{pH}$ tests with the universal indicator and other experiments the students can tackle during the experimental activity proposed in this DS.

\section{Lesson by lesson description}

Lesson 1: How does science help us solve problems?

This lesson began with a practical problem, like the following example (hypothetical case):

\section{A 32-year old erstwhile healthy female began to show sign of hyperten-} sion $(P A=160 \times 100 \mathrm{mmHg})$ and oedema in the lower limbs and face three months ago. She denies haematuria, dyspnoea and orthopnoea. After developing his hypothetical diagnoses, the doctor requested two urine tests: urine sediment examination (USE, also known as urine 1); in the other sample, which consisted of a 24-hour urine collection, a substance X was purified without loss. It is your group's task to perform the quantitative (weight) and qualitative analysis of this substance.

Based on the problematization approached, the students were asked to develop a plan of justified, experimental activities, including the main urine components that could be chemically identified. The experimental problem was guided by the following question: How can we identify the chemical components of the urine? How can these components be identified? At this point, the contents of boxes 1 and 2 (Table 2) were presented for familiarization. These materials were duly organized and labelled to generate intrigue and be easy to handle, and, in groups, the students were able to discuss and explore situations from a scientific perspective, proposing explanatory hypotheses and possible experimental paths.

This first contact with the apparatus, albeit in a classroom, was important for preparing the students for the subsequent step: planning and systematization of the analyses of the standard solutions based on the materials supplied.

\begin{tabular}{|c|c|}
\hline \multicolumn{2}{|c|}{$\begin{array}{l}\text { TABLE } 2 \\
\text { Content of boxes } 1 \text { and } 2 \text { delivered to } \\
\text { the students for the planning }\end{array}$} \\
\hline Box 1: "reagents" & Box 2: "standard solutions" \\
\hline $\begin{array}{l}\text { 1. } \mathrm{CuSO}_{4} 1 \% \\
\text { 2. } \mathrm{NaOH}_{2.5 \mathrm{~mol} / \mathrm{L}} \\
\text { 3. } \mathrm{AgNO}_{3} 0.1 \mathrm{~mol} / \mathrm{L} \\
\text { 4. Sodium citrate } 10 \% \\
\text { 5. Tincture of iodine } \\
\text { 6. } \mathrm{HCl} 1.0 \mathrm{~mol} / \mathrm{L}\end{array}$ & $\begin{array}{l}\text { 1. Sodium chloride - standard solution of } \\
\text { sodium and chloride ions } \\
\text { 2. Sulphur } \\
\text { 3. Calcium chloride - standard solution of } \\
\text { calcium and chloride ions } \\
\text { 4. Sodium bicarbonate - standard solution } \\
\text { of bicarbonate and sodium } \\
\text { 5. Albumin } \\
\text { 6. Urea } \\
\text { 7. Starch } \\
\text { 8. Lipid } \\
\text { 9. Glucose } \\
\text { 10. Ammonium chloride - standard solution } \\
\text { of ammonia and chloride }\end{array}$ \\
\hline
\end{tabular}

Source: Authors.

To steer the student's curiosity, the following question was put to the groups: what are the reference values of these components in normal urine? Thus the planning process began, using physical or digital resources, involving research in the literature in the field and reflecting on experimental and clinical possibilities, always guided by the teachers. All the observations, doubts and results were noted in a lab notebook belonging to the group.

\section{Lesson 2: Getting your hands dirty}

The objective of this class, which can be developed either in the classroom or the laboratory, was to gain a practical understanding of the concept of standard solution samples and reagents, correlating alterations of the chemical components studied to possible pathologies. Continuing lesson 1 , the following question was problematized: which chemical/biochemical components may have their values altered according to the clinical case? This was the moment that the association was made with the clinical case by raising hypotheses, as well as realizing that we could not conduct experiments "random$1 y^{\prime \prime}$, due to factors such as time and consumption of reagents, among others. This was the moment to choose which standard solutions would be most "likely" to elucidate the clinical case and discover how it is possible to develop analysis strategies based on the reagents provided and conduct these experiments, physicochemical tests, with the available experimental apparatus. In order to do this, the students had two boxes of reagents (Table 2), one identified as "standard solutions" and the other box identified as "reagents", as well as the unknown sample " $X$ ", introducing the concepts of analyte, reagent and standard solution. 
At this moment, they experienced the contents of the two boxes, opened the bottles and explored the material. From this moment on they began a group discussion about which "standard solutions" could be related to the clinical case, that is, which one could indicate a diagnosis, and also outlined a sequence of analyses that systematized theoretical-practical knowledge. All the propositions, following the research conducted by the group, were noted in the group's lab notebooks and copies forwarded to the teacher.

\section{Lesson 3: What is the mass of sample " $X$ "?}

In this experimental lesson, conducted in the laboratory, the students experienced the activity of weighing on an analytical scale. The groups were initially posed the question: what is the mass of sample " $\mathrm{X}$ "?

On the blackboard they found the following information about unknown sample " $X$ " (analyte):

I. Solid substance at ambient temperature, soluble in distilled water

II. Concentration in the solution where sample " $X$ " was found is $0.05 \mathrm{~g} / \mathrm{mL}$ and was diluted ten times.

III. The mass of the empty bottle with the lid was noted on the bottle.

$I V$. The sample contains precisely $10 \mathrm{~g}$ of solvent, in this case, distilled water.

$V$. Whatever glassware and equipment they deem necessary, within the proposal and the possibilities of the teaching laboratory, could be requested.

The groups proposed the use of the analytical scale. Once the sample was weighed, they obtained through simple calculation the mass of the solute. At this point, it is helpful if the teacher or technician helps with the weighing, as the groups will get a quick explanation of the standard operation of a laboratory balance.

On this occasion, strategies and calculations were also recalled that involve the concepts of solutions, dilution and weighing, which are very important for medical practice, whether in the interpretation of an examination, in the administration of a soluble medication, or other activities.

Considering the errors, the quantity found should be 4.5 $\mathrm{g}$ of solute (albumin, however at this point this information was still not known by the groups) in a hypothetical 24-hour urine sample.
Lesson 4: What is sample " $X$ "?

In this experimental class, also conducted in the laboratory, the students were approached with the following question: What is the chemical/biochemical composition of sample " $X$ "?

Each group followed its plan, requesting help when necessary. At this time, the teacher should police the dialogue, taking care not to give away the answer. Skills related to procedural contents were developed during the manipulation, heating and weighing, as well as attitudinal contents being developed (the time was relatively short). The students had to organise themselves and work as a team. They also realised that, in some cases, the planning had been insufficient to resolve the problem, and re-planning was required, which is a common occurrence in medical activities. Throughout the whole time, they could use their mobile phones as a research tool and ask the teacher and lab technician questions.

\section{Lesson 5: How reliable is the result?}

Once the analyte and its concentration were found, the groups were questioned about the reliability of their results. Therefore, the following question was posed: How can you be sure of the result? At this point, the discussion revolved around the importance of repeating the experiment with unknown sample " $X$ " and the albumin standard solution in the same experimental conditions, the method and steps of which should be proposed by the group, for it is important to know that in laboratorial analysis results must be confirmed using the same procedure in the same experimental conditions - that is, using the same quantity of analyte and of reagents, analysis sequence and reaction time - thus validating the method and the result. At this stage, each group created a different protein analysis protocol, which was briefly discussed. It is expected that the students learn that techniques can be created based on standard solutions and reagents, which we can adapt or rearrange for certain analyses, thus overcoming dogmas regarding the methods, indicating that some adaptations can be made, provided they are standardized, previously tested and theoretically grounded. This notion of standardization is important, for is guarantees the reliability and confidence by saying: sample " $\mathrm{X}$ " contains a certain quantity of protein. The student should reflect and feel confident about manipulative practices in chemistry, and on the need for adaptations, such as for example, the need to dilute a drug.

\section{Lesson 6: How does a Clinical Analysis Laboratory} (CAL) work?

In this final stage, the students were split into two groups and visited a CAL, where they learned about the work routine of 
the professionals in that area. The students discussed the main tests and equipment, with particular focus on urinalysis. At this point, the following question was raised for reflection: How is chemistry/biochemistry related to the diagnosis of pathologies?

The groups had contact with standard laboratory analyses kits and answered the following problematizing question: How can a biochemical test be done for protein identification? They performed practical tests, in which they were attentive to key questions, such as expiration date and methodologies of utilization, among others. Having contact with the analysis kits in this final stage of the didactic sequence, the students were able to understand ho raw analyses can be refined, generating safe and rapid tests, which helps in the fast diagnosis of some pathologies.

\section{RESULTS AND DISCUSSION}

From this perspective, the didactic sequence involving investigative, experimental activities can be used as a teaching strategy to relate and improve understanding of basic and clinical concepts, which are generally specific and complex contents. Clear and well-developed didactic sequences, which involve investigative, experimental activities would be a good alternative for faculty and students, as they can support and explain the educational processes, bearing in mind the heterogenous profile of the students, who, in the majority of cases, complete high school with scarce practical experiences.

The result found for the solution to the problem, that is, the identification of sample " $X$ ", was given by the biuret reaction, suggesting the presence of protein whose previously determined mass corresponds to roughly 4.5 grams. All the groups successfully arrived at the final result.

Table 3 presents the relative reference values and suggested potential clinical correlations, which require discussion in the summary activity for the correct formulation of the concepts acquired in this sequence.

At this point, the teacher should pose questions of an elevated cognitive order to the students, associating fundamental concepts and correlating all the stages.

The opening in the experimental activity exposed here results in a level of high cognitive demand ${ }^{20}$, since the students developed their own procedures to test the hypotheses presented and selected for investigation. With the teacher's mediation, the students were able to successfully perform their own experiments and test their hypotheses to solve the problem. The teacher's questions, therefore, played a key role, since thanks to this mediation the students effectively engaged in the learning process, with their interest being directly linked to the learning. Furthermore, we know that one cannot expect the student to develop a highly cognitive response if he is not stimulated in that direction ${ }^{21,22}$.

Yardenet al. ${ }^{23}$, in a study conducted to identify the cognitive level of questions developed by students, found that the cognitive level of the students' responses is determined by the type of question posed by the teacher. These assertions reinforce the importance of the teacher's mediation in the construction of knowledge by contemporary students.

The chemical components sulphur, starch and lipid were discarded by all the groups, since the students knew that it was impossible that any of these would be found in a urine

TABLE 3

Reference value* in normal urine of the chemical components used in the activity and possible clinical correlations

\begin{tabular}{|c|c|c|}
\hline Standard Solution & Reference values* & Examples of related pathologies \\
\hline 1. Sodium & Fraction of excretion $<1 \%$ ( $<2.5 /$ day $)$ & Chronic kidney disease \\
\hline 2. Sulphur & 0 & Ingestion of food like asparagus, fish, onion, garlic, and others \\
\hline 3. Calcium & $<4 \mathrm{mg} / \mathrm{kg} /$ day $(<250 \mathrm{mg})$ & $\begin{array}{l}\text { The excess calcium in the urine can indicate stones in the } \\
\text { urinary tracts or nephritis }\end{array}$ \\
\hline $\begin{array}{l}\text { 4. Sodium bicarbonate (bicarbonate } \\
\text { and sodium ions) }\end{array}$ & Fraction of excretion $<5 \%$ & Ketoacidosis \\
\hline 5. Albumin & $<30 \mathrm{mg} /$ day & Proteinuria - nephrotic syndrome \\
\hline 6. Urea & Fraction of excretion $<35 \%$ & None, but could indicate dehydration \\
\hline 7. Starch & 0 & None \\
\hline 8. Lipid & 0 & None \\
\hline 9. Glucose & Fraction of excretion $<0.15 \%$ & Diabetes mellitus \\
\hline $\begin{array}{l}\text { 10. Ammonium chloride (ammonia and } \\
\text { chloride ions) }\end{array}$ & $26-68 \mathrm{uEq} / \mathrm{min} / 1.73 \mathrm{~m} 2$ & Dehydration \\
\hline
\end{tabular}


sample, even of a sick patient. Therefore, the tests with these compounds were not considered or performed by any group. On the other hand, the students in the early stages of training were interested in performing exploratory experiments, which despite not being relevant to the clinical case, triggered the students' curiosity, since it was the first such experimental experience for many of them. As examples, flame tests of sodium and potassium ions were executed as well as reactions of starch-iodine complex, among others.

At the end of the didactic sequence, in the summary activity, the groups discussed their results, the practical paths and their grounding (Figure 1). They all assertively reached the final result and could confirm, with confidence and precision, the diagnosis of proteinuria, discussing the main causes and possible treatments.

\section{CONCLUSION}

The Health Science undergraduate courses offered at public and private institutions in Brazil are currently adhering to a new teaching modality, based on active methodologies. The teachers, in turn, exert their best efforts to contextualize the contents, however they find difficulties in integrating some concepts, due to their specificity and complexity, since the teachers of these courses have been trained in specific fields of Medicine, Biology and Pharmacology, among others. It is important to underline that a DS like the one documented here can be transformed and adapted in accordance with the need, since the groups of students are different. Furthermore, these activities are adjusted to the new teaching method, recently adopted by the main universities, and based on problem-solving in active methodologies and PBL. Therefore, the students are able to integrate concepts of basic biochemistry and their foundations and observe how important they are, as their specific chemical properties are used to perform physio-pathological analyses, integrating concepts and making the learning more attractive and interesting.

We believe that investigative didactic sequences can help develop specific skills, enhancing the teaching and learning process. In this regard, we should dynamize dialogues practiced in the construction of knowledge founded on the exchange of knowledge coming from multiple and various areas, with the aim of interconnecting concepts and contents.

Reflecting on the perceptions obtained in this experience, we propose that investigative didactic sequences can provide a systematized teaching of specific and complex concepts, integrating different fields of knowledge and ensuring effective student participation. In this proposal, the student will have the freedom to plan their experiment, make mistakes, try again, discuss hypotheses, work in groups, to develop cognitive skills through associations between basic and clinical science, reflecting on the construction of medical knowledge.

\section{ACKNOWLEDGEMENTS}

Thanks to Thelma Lopes da Silva (Laboratory Specialist, FOB - USP), Silvia Cristina Arantes (Head of the Technical Session of the Clinical Analyses Laboratory of HRAC - USP) and to the students of the first class of Medicine at FOB - USP Bauru.

\section{REFERENCES}

1. Barrows HS. A taxonomy of problem-based learning methods. MedEduc, Nov, 20(6),481-6, 1986.

2. Conceição CV, Moraes MAA. Aprendizagem Cooperativa e a Formação do Médico Inserido em Metodologias Ativas: um Olhar de Estudantes e Docentes. Revista brasileira de educação médica, Brasília, 42(4), p. 115-122, Dezembro de 2018. Available at: http://www.scielo.br/scielo. php?script=sci_arttext\&pid=S0100-5022018000400115\&ln $\mathrm{g}=\mathrm{en} \& \mathrm{nrm}=$ iso. Acesso em 26 de Março de 2019.

3. Prado W. Desenvolvimento e implantação da nova estrutura curricular na faculdade de medicina de ribeirão preto: dificuldades e avanços. Medicina (Ribeirão Preto. Online),29(4), 373-382, 1996. Available at: https://doi. org/10.11606/issn.2176-7262.v29i4p373-382. Acesso em 30 de Março de 2019.

4. Universidade de São Paulo. Proposta do Projeto Pedagógico do Curso de Medicina de Bauru, Universidade de São Paulo. Available at: https://uspdigital.usp.br/jupiterweb/jupCarreira.jsp?codmnu=8275. Acesso em 04 de Março de 2019.

5. Zabala A. Prática Educativa: como ensinar. Porto Alegre: ARTMED, 1998

6. Domin DS. A Review of Laboratory Instruction Styles. Journal of Chemical Education, 76 (4), 543-547, 1999.

7. de Souza FL, Akahoshi LH, Marcondes MER, do Carmo MP. Atividades experimentais investigativas no ensino de química. São Paulo: EDUSP, 2013. Disponível em: http:/ / media.wix.com/ugd/4eb63d_e80a97ccab0e484b9582e3e7dfe129f5.pdf. Acesso em02 de Janeiro de 2019.

8. Suart RC, Marcondes MER. A manifestação de habilidades cognitivas em atividades experimentais investigativas no ensino médio de química. Ciência \& Cognição, 14(1), 5074,2009

9. Chaves CD. Controle de qualidade no laboratório de análises clínicas. Jornal Brasileiro de Patologia e Medicina Laboratorial, 46(5):352, 2010.

10. Capilheira MF, Santos IS. Epidemiologia da solicitação de exame complementar em consultas médicas. Revis- 
ta Saúde Pública, São Paulo, 40(2), 289-297, April 2006. Available at: http:/ / www.scielo.br/scielo.php?script=sci arttext\&pid=S0034-89102006000200015\&lng=en\&nrm =i so. Acesso em 02 de Abril de 2019.

11. Cézar FM. Controle de qualidade laboratorial: uma atualização em urinálise.UniversidadeFederal do Paraná, 29p, 2016.

12. Russo LM, Sandoval RM, Mckee M, Osicka TM, Collins AB, Brown D, et al. The normal kidney filters nephrotic levels of albumin retrieved by proximal tubule cells: retrieval is disrupted in nephrotic states. 71(6):504-513, Kidney Int. 2007.

13. Bastos MG, Bregman R, Kirsztajn GM. Chronic kidney diseases: common and harmful, but also preventable and treatable. Revista da Associação Médica Brasileira, 56(2):248-253, 2010.

14. Guh JY. Proteinuria versus albuminuria in chronic kidney disease. Nephrology (Carlton), 15(Suppl 2):53-56, 2010.

15. Volpe M, Cosentino F, Ruilope LM. Is it time to measure microalbuminuria in hypertension? Journal of Hypertension, 21(7):1213-1220, 2003.

16. Clausen P, Jensen JS, Jensen G, Borch-Johnsen K, Feldt-Rasmussen B. Elevated urinary albumin excretion is associated with impaired arterial dilatory capacity in clinically healthy subjects. Circulation, 103(14):1869-1874, 2001.

17. Ginsberg J, Chang BS, Matarese RA, Garella S. Use of single voided urine samples to estimate quantitative proteinuria. The New England Journal of Medicine, 309:15431546, 1983.

18. Hou FF, Zhang X, Zhang GH, Xie D, Chen PY, Zhang WR, et al. Efficacy and safety of benazepril for advanced chronic renal insufficiency. The New England Journal of Medicine, 354(2):131-140, 2006.

19. Kunz R, Friedrich C, Wolbers M, Mann JF. Meta-analysis: effect of monotherapy and combination therapy with inhibitors of the renin angiotensin system on proteinuria in renal disease. Annals of Internal Medicine, 148(1):30-48, 2008.

20. Zuliani SRQA. A utilização da Metodologia Investigativa na Aprendizagem de Química Experimental. Dissertação de mestrado em Educação para as Ciências. Faculdade de Ciências, Universidade Estadual Paulista Julio de Mesquita Filho, Bauru, São Paulo, 288p, 2000.
21. Sasseron LH, Carvalho AMP. Construindo argumentação na sala de aula: a presença do ciclo argumentativo, os indicadores de alfabetização científica e o padrão de toulmin.Ciência e educação, Bauru, São Paulo, 17(1),97114, 2011. Available at: http://www.scielo.br/scielo. php?script=sci_arttext\&pid=S1516-73132011000100007\&ln $\mathrm{g}=\mathrm{en} \& n r m=$ iso. Acesso em 02 de Abril de 2019.

22. Carvalho AMP. Ensino de ciências por investigação: condições para implementação em sala de aula. São Paulo: Cengage Learning, 2013.

23. Yarden A, Brill G, Falk H. Primary literature as a basis for a high-school biology curriculum. Journal of biological education, 35, 190-195, 2001.

\section{AUTHORS' CONTRIBUTION}

Prislaine Pupolin Magalhães: Responsible for the creation and application Investigative Didactic Sequence.

Rodrigo Cardoso Oliveira: Responsible for the content and discussions in Biochemistry.

Daniela Ponce: Responsible for Nephrology contents and discussions.

Silvia Regina Quijadas Aro Zuliani: Responsible for the pedagogical orientation.

\section{CONFLICT OF INTEREST}

The researchers say there are no conflicts of interest.

\section{CORRESPONDENCE ADDRESS}

UNESP - Universidade Estadual Paulista - Campus Bauru Departamento de Educação

Av. Eng. Luiz Edmundo Carrijo Coube, 14-01 - Vargem Limpa - Bauru/SP - CEP 17033-360

Telefone: (14) 3103-6000 - Fax: (14) 3103-6000 